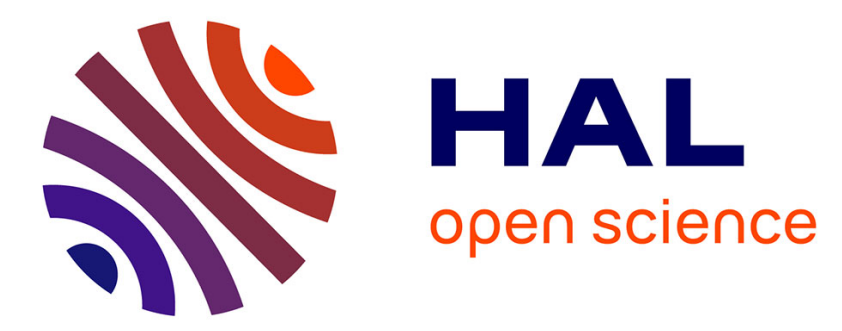

\title{
Micromorphological analysis of soil structure modifications caused by different cultivation implements

\author{
Anne Gebhardt
}

\section{To cite this version:}

Anne Gebhardt. Micromorphological analysis of soil structure modifications caused by different cultivation implements. PREHISTOIRE DE L'AGRICULTURE, NOUVELLES APPROCHES EXPERIMENTALES ET ETHNOGRAPHIQUES Monographie du CRA, 40, Institute of archaeology, Univ. of California, LA, 260- 266, 1999. hal-02278795

\section{HAL Id: hal-02278795 \\ https://hal.science/hal-02278795}

Submitted on 4 Sep 2019

HAL is a multi-disciplinary open access archive for the deposit and dissemination of scientific research documents, whether they are published or not. The documents may come from teaching and research institutions in France or abroad, or from public or private research centers.
L'archive ouverte pluridisciplinaire HAL, est destinée au dépôt et à la diffusion de documents scientifiques de niveau recherche, publiés ou non, émanant des établissements d'enseignement et de recherche français ou étrangers, des laboratoires publics ou privés. 
PREHISTOIRE DE L'AGRICULTURE, NOUVELLES APPROCHES EXPERIMENTALES ET ETHNOGRAPHIQUES Monographie du CRA nº 6. éd. CNRS. 1992, p.373-381

(réédition 1999, Prehistory of agriculture, new experimental and ethno ghraphic approaches. P. Anderson (ed), Monographie du CRA, 40, Institute of archaeology, Univ. of California, LA, 260266)

\title{
Micromorphological analysis of soil structure modifications caused by different cultivation implements.
}

\section{Gebhardt Anne}

\begin{abstract}
RESUME
Au cours des expérimentations en archéologie agraire. les sols ont eté laisses un peu a l'écart des investigations. Ce travail basé sur la micrornorphologie, a permis l'observation de la microstructure de différents sols expérimentaux cultivés. Nous avons mis en évidence des traits structuraux caractérisant le mode d'exploitation employé. Par ailleurs, il nous est apparu que la durée de l'experience est difficile à raccoucir et qu'avec chaque outil, le sol réagit selon sa nature.

ABSTRACT

Soil studies have been largely neglected in experiments related to agrarian archaeology. The present study is based on soil micromorphology and involves observations of the micro-structure of different soils in cultivation experiments. We have shown there are structural traits characteristic of the method ofsoil-working used. Otherwise. the experiments need to take place over a fairly long duration, difficult to reduce, and we have also seen that each soil reacts according to its particular properties as well as the type of tool used.
\end{abstract}

\section{INTRODUCTION}

Experimental agriculture in archaeology has recently appeared in Europe in order to understand plant change through domestication and to this end seed collections have been made, and ancient crops have been cultivated and theiryields studied. Experirnenters have also been interested in the use of reconstructed ancient tools such as sickles, and the microwear traces which form on them. However, in these experiments soils have been largely ignored.

\section{Soil studies}

In archaeolog/, the anthropogenic impact occuring on the agrarian landscape should be studied through the soil because soil supports cultivation and supplies the plant with its nutrients, and it also records the intervention of man and his cultivation implement. The latter is best studied through mieromorphology : Chemical analyses routinely used in pedology $(\mathrm{pH}$, organic matter, cation exchange characterisation, base saturation, etc.) only characterise the present- day state of a soil and provide very little information on its ancient evolution.

\section{a. Methodology}

Micromorphology, a new method of investigation of soils, has been use in archaeology for about ten years. first in England (Romans and Robertson, 1983 : Macphail, 1986), then in France [Courty, 1982). Perfected by pedologists, it allows microscopic study of undisturbed loose sediments, sampled in oriented blocks. The samples are then dried, hardened by polyester resin. sliced into slabs and machined down to $25 \mathrm{pm}$ to allow observation under the polarizing microscope. It is then possible to recognize a number of sedimentary, pedological and anthropogenic features which characterize the natural deposit. its degree of pedological evolution and the type of anthropogenic disturbances affecting it. This helps give a better understanding of the change induced by man on his environment at a number of levels (cf organization of his habitat, agricultural exploitation of the surrounding landscape). In the last case, micromorphology can detect features directly related to the agricultural exploitation of a field, on the condition that the soil remains well-protected from modern fauna and agricultural disturbance [buried under an archaeological monument]. 


\section{b. Topics}

Under many archaeological monuments. we can fincl well-dated ancient soils preserved from alteration. Unfortunatly it is sometimes difficult to interpret certain pedological features because of a lack of reference material. Therefore, in order to make a reference collection of cultivated profiles to compare with those coming from archaeological contexts. different profiles from experimental sites in north-west Europe have been sampled. Interest is concentrated upon structural modifications caused in the soil by various cultivation implements, with structure and porosity both being important factors in soil suitability for agriculture (Fedoroff, 1986]. These play an essential part in the migration ofwater, solid particles, exchangeable bases ( $\mathrm{Na}, \mathrm{K}, \mathrm{Ca}, \mathrm{Mg}$ ), and for iron and aluminium movement. Porosity, which can have a mechanical origin (fissures, cracks), or be biologically formed by animal holes (channels, burrows). encourages plant root growth. For the present work. the stnicture of thin-sections was observed through a stereoscopic microscope using the method described by Bullock et al. (1985).

c. The experimental sites

These were all chosen in north west Europe in order to maintain a pedo-climatic unity and to allow better comparisons between these results and those from the archaeological sites studied.

They are :

- Butser Farm (Great Britain) : an experimental Iron Age farm where the fields have been ploughed with an ard since 1970. This site is situated on calcareous colluvium. at the bottom of a grassy hill used for pasture (Reynolds, 1984].

- Hambacher Forst (Germany) : a loessic-loam soil under forest has been ploughed with an ard for one year by U. Tegmuller (Meurers-Balke, 1985).

— The Grignon forest (France. Institut National Agron0mique): a loessic-loam was worked with a wooden hoe of Neolithic type. In order to accelerate the pedological process the experimental plots were intensively watered for one month [about 2000 litres in July 1986).

- The Deherain plots (France. Institut National Agronomique) : these are established on calcareous colluvium under grassland to study the influence of different types ofmanuring on crop yield.

Several plots have been worked with a spade or a cultivator since 1929 (Morel et al.. 1984)

These four experiments can be divided into two groups (table 1) :

- Soils on calcareous colluvium under grassland (Butser, Deherain)

- Soils on loessic»loam under forest (Hambacher Forst. Grignon).

Four ways of working the soil are compared :

— Working with a hoe (Grignon)

— Working with an ard (Butser. Hambacher Forst).

- Working with a spade (Deherain).

— Working with a cultivator (Deherain. Hambacher Forst).

All of these sites have an uncultivated soil for reference.

On manured Deherain plots. the influence of different organic matter input on soil structure was also studied (table 2).

\section{RESULTS}

\section{Tool impact on soil structure}

Table Ill summarises the micromorphological observations of the upper horizon structure (A for uncultivated horizon, Ap for ploughed horizons) from the experimental soils studied.

For each sort of implement. a number of variables were compared. These are the degree of compaction of the soil and its porosity, ped form and shape, depth of organic matter burial. and the depth of tool impact, which determines the extent of the Ap horizon. In all cases. the s0il's initial structure is very compacted and well-structured. with characteristic 'bird foot-shaped' cracks (with 3 or 4 radiant junctions) isolating soil peds (fig. 1 and fig. 2). Significant biological activity 
occurred. suggested by animal pellets and root remains. and its increased porosity. shown by channels and burrows (fig. 2 and fig. 3). The loessic-loam at Hambacher Forst is very compact (fig. 4], but less porous. The structure collapsed because the original A horizon was badly structured. After cultivation. the soil becomes looser ; the structure is made up ofclods of different sizes according to the tool cniployed (fig. 6. lig. 7 and fig. 9]. mixed with smaller angular peds. In the middle of the biggest clods. the original soil structure is still well preserved.

At Hambacher Forst (fig. 7). clods do not exist because of the badly-structured nature of the original horizon 1 but we can observe numerous rounded peds, in the groundmass compacted by the ard. The bottom of the ploughed horizon is compacted into a discontinuous. thin loamy-clay zone (1 $\mathrm{cm}$ ), is lamellar in structure, and creates a plough pan like those described in modern ploughed horizons (Jongerius, 1970 ; Collins and Larney, 1987). In addition, the cultivator created clods with straight, cleanly-broken edges (fig. 10). On the other hand, unfortunately. the hoeing experiment at Grignon did not show real disturbance, with the exception of an increase in star-shaped porosity (fig. 5) : this was certainly caused by excessive watering of the plots over too short a time (Courty, 1988).

\section{Modifications caused by manuring}

\section{Structure :}

Input of organic matter in the form of pure straw, humidified straw, or stable litter does not affect the structure of any horizon, worked or not. Only the increasing quantity of organic fragments, more or less incorporated into the soil, gives evidence of this input.

Organic activity (table 4) :

Traces of faunal activity seem to be more visible in the uncultivated, unmanured plots, than under the ploughed horizons. Whatever the treatment of the plot, tnicrofauna (Oribatids, Enchytraeids) are more abundant than mesofauna (Earthworms). Working the soil hides or destroys traces of organic activity which remain visible deeper in the soil profile.

\section{DISCUSSION}

It follows from this work that the type of agricultural exploitation of a soil may be recognised by studying soil structure. As a matter of fact, certain quantities of recognizable structural features (little clods. big cleanly broken clods, plough pan) which we found are characteristic of the tool used (hoe, cultivator, ard). This work also reveals the importance of two experimental factors: First, the time factor of the experiment, which is very difficult to moderate : as we have seen, in trying to accelerate time, the experimenter only changes the natural pedological processes (Grignon). Second, the soil type, which will behave differently according to the tool used.

At the moment, the experimental sites are all situated in different environments, on soils which are similar but not quite the same. To increase the reliability of these results, we will need to compare a large number of cases. In the future, other sites like the « Ferme Archeologique de Melrand » (Morbihan, France] or the Lejre experimental center (Denmark) will be investigated.

Unfortunately, as no archaeological experiment has been started on the original Atlantic forest soil. We must be satisfied with extrapolation from more recent soils, with structures which are similar but no identical. Besides these, there is another factor which we don't understand very well, the behaviour of these structures as they age. The weight of sediments, or of any archaeological construction which seals a site, can modify the soil structure. Therefore, when the experimental results are compared to archaeological buried soils protected from modern anthropogenic disturbance. we will have to take such structural modifications into account.

\section{CONCLUSION}

Through this work, we could observe the micromorphological structure of different experimental soils cultivated using different tools and manuring. The small number of soils actually considered and their great pedological diversity, will lead us to multiply observations in other experiments 
using different tools. Then we will need to compare them with ancient cultivated soils to be able to recognize ancient techniques used in the past for working a field.

\section{ACKNOWLEDGEMENTS}

I would like to thank Drs R.1. Macphail [Institute of Archaeology, London) and P, Anderson (Institut de Prehistoire Orientale. Jales) for their help with the English version of this article.

\section{REFERENCES}

Bullock P., FedoroffN., Jongerius A.. Stoops G.. Tursina T., Babel U.. 1985,- Handbook for soil thin section description. Wciine Research Publication. 150 p.

Collins J.F.. Larney F.J.. 1987.- Micromorphological observations of compacted horizons

(cultivated pans) from various horizons in Irish tillage soils. In : Soil Micromorphology, Fédoroff N.. Bresson L.M.. and Courty M.A.( eds] : 451-457.

Courty M.A.. 1982.- Etude geologique de sites archeologiques 1-lolocenes : définition des processus sedimentaires et post-sédimentaires. caraclérisation de l'impact anthropique. Essais de methodologie. These de 39 cycle de Géologie du Quaternaire et préhistoire (Bordeaux I), $310 \mathrm{p}$. Courty M.-A. Trichet J., 1988,- Application de la micromorphologie à la caractérisation des Sols anciens cultivés, 25 colloque Franco-souiétique sur Farchéologie de l'Asie Centrale des origines àl'AgeduFer(Paris 1985), Boccard : 237-241.

Fédoroff N., 1987,- Sensibilité à l'agriculture intensive des principaux types de sols de l'Europe du Nord-Ouest. Actes du Symposium « Fondements scientifiques pour la protection des sols dans la Communauté européenne, (Berlin. 6-8 octobre 1986). Barth et l'Hermile : 65-87.

JongeriusA.. 1970.-Some morphological aspects of regrouping phenomena in Dutch soils, Geoderma vol. 4 : 311-331.

Macphail R.I.. 1986,- Paleosols in Archeology : their role in understanding Flandrian pedogenesis, in : V. Paul Wright (ed.) Paleosols : their recognition and interpretation : 263-290.

Meurers-Balke J.. 1985.- Experimente zum Anbau und zur Verarbeiterung prähistorischer

Getreidearten. Archäologische Inforrriatiorlen. tome 8. cahier 1: 8-17.

Morel R., Lasnier Th.. Bourgeois S., 1984.- Les essais de fertilisation de longue durée de la station agronomique de Grignon. Dispositif Deherain et des 36parcelles. Resultats experirnentaux [periode 1938-1982). publication INRA Paris-Grignon.

Reynolds P.J.. 1984.- Deadstock and livestock, in Farming Practice in British Prehistory. Roger Mercer (ed.) : 97-122.

Romans J.C.C. and Robertson L., 1983.-The general effect of early agriculture on the soil profile. C. BAR Report. $\mathrm{N}^{\circ} 49: 14$ p. 
Table 1 The different experiments used for structural analysis of cultivated soils

\begin{tabular}{|l|c|c|c|c|}
\hline & \multicolumn{2}{|c|}{ CALCAREOUS COLLUVIUM UNDER GRASSLAND } & \multicolumn{2}{c|}{ LOESSIC-LOAM UNDER FOREST } \\
\hline & BUTSER & DEHERAIN & GRIGNON & HAMBACHER FORST \\
\hline TOOL & & & & $\mathrm{X}$ \\
\hline Uncultivated & $\mathrm{X}$ & $\mathrm{X}$ & $\mathrm{X}$ & $\mathrm{X}$ \\
\hline Hoe & $\mathrm{X}$ & & & $\mathrm{X}$ \\
\hline Srd & & $\mathrm{X}$ & & \\
\hline Cultivator & & $\mathrm{X}$ & & \\
\hline
\end{tabular}

Table 2 The Deherain plots used for analysis of the influence of manuring on soil structure

\begin{tabular}{|l|c|c|c|c|}
\hline & WITHOUT MANURING & $\begin{array}{c}\text { STRAW WITHOUT } \\
\text { PREHUMIFICATION }\end{array}$ & $\begin{array}{c}\text { STRAW WITH } \\
\text { PREHUMIFICATION }\end{array}$ & STABLE LITTER \\
\hline Spade & $\mathrm{X}$ & $\mathrm{X}$ & $\mathrm{X}$ & \\
\hline Cultivator & $\mathrm{X}$ & & & $\mathrm{X}$ \\
\hline
\end{tabular}

Table 3 Comparative structure of soils worked with different tools by site (D:diameter)

\begin{tabular}{|c|c|c|c|c|c|c|}
\hline & SOIL & POROSITY & PEDS & ORGANIC MATTER & COLOR & $\begin{array}{l}\text { DEPTH OF } \\
\text { IMPACT }\end{array}$ \\
\hline \multicolumn{7}{|c|}{ UNCULTIVATED } \\
\hline Butser & Compact & $\begin{array}{l}\text { Bird foot-shaped cracks } \\
\text { (fig 26.1) }\end{array}$ & Homogeneous (D 2m) & In small quantity chipped & Brown & / \\
\hline Deherain & $\begin{array}{l}\text { Quite } \\
\text { compact }\end{array}$ & $\begin{array}{l}\text { Relatively well opened } \\
\text { (fig 26.2) }\end{array}$ & $\begin{array}{l}\text { Relatively compacted } \\
(0.5<\mathrm{D}<1 \mathrm{~cm})\end{array}$ & $\begin{array}{l}\text { Important biological } \\
\text { activity (pellets, plant } \\
\text { fragments, numerous } \\
\text { channels) }\end{array}$ & Light brown & I \\
\hline Grignon & Compact & $\begin{array}{l}\text { Bird foot—shaped } \\
\text { crackschannels. } \\
\text { Chambers (fig 26.3) }\end{array}$ & Few $(\mathrm{D} 0.5 \mathrm{~cm})$ & $\begin{array}{l}\text { Medium biological } \\
\text { activity (intense upwards, } \\
\text { some pellets at bottom) }\end{array}$ & Light brown & / \\
\hline Hambacher Forst & Compact & No cracks (fig 26.4) & $\begin{array}{l}\text { Coming from B horizon } \\
\text { (lighter) disturb the A } \\
\text { horizon homogeneity }\end{array}$ & $\begin{array}{l}\text { Intense biological activity } \\
\text { (animal burrow roots, } \\
\text { numerous plant remains) }\end{array}$ & Dark color & 1 \\
\hline \multicolumn{7}{|c|}{ HOE } \\
\hline Butser & 1 & 1 & / & 1 & 1 & / \\
\hline Deherain & 1 & 1 & 1 & 1 & 1 & 1 \\
\hline Grignon & $\begin{array}{l}\text { Quite } \\
\text { compacted }\end{array}$ & $\begin{array}{l}\text { Packing void porosity } \\
\text { (cham-bers with star- } \\
\text { shaped concave walls); } \\
\text { bird foot-shaped cracks } \\
\text { have disappeared } \\
\text { (fig 26.5) }\end{array}$ & / & 1 & Light brown & Undefined \\
\hline Hambacher Forst & 1 & 1 & 1 & 1 & 1 & 1 \\
\hline \multicolumn{7}{|c|}{ ARD } \\
\hline Butser & $\begin{array}{l}\text { Medium } \\
\text { compacte, } \\
\text { intensive } \\
\text { disintegra- } \\
\text { tion (with- } \\
\text { out orien- } \\
\text { tation) }\end{array}$ & $\begin{array}{l}\text { Connected chambers } \\
\text { and cracks }\end{array}$ & Quite angular & 1 & / & Undefined \\
\hline Deherain & 1 & 1 & 1 & 1 & 1 & / \\
\hline Grignon & 1 & 1 & 1 & 1 & 1 & 1 \\
\hline Hambacher Forst & compacted & Unfissured & $\begin{array}{l}\text { Rouded (D:0,5cm), } \\
\text { darker than the ground- } \\
\text { mass, plough pan (fig } \\
\text { 26.7) }\end{array}$ & $\begin{array}{l}\text { Numerous big organic } \\
\text { fragments }\end{array}$ & 1 & $6 \mathrm{~cm}$ \\
\hline \multicolumn{7}{|c|}{ SPADE } \\
\hline
\end{tabular}




\begin{tabular}{|c|c|c|c|c|c|c|}
\hline Butser & / & / & / & / & 1 & 1 \\
\hline Deherain & $\begin{array}{l}\text { Little } \\
\text { compac- } \\
\text { tion }\end{array}$ & $\begin{array}{l}\text { Horizontal cracks } \\
\text { everywhere; biggest } \\
\text { clods are compacted, } \\
\text { with star-shaped cracks } \\
\text { (fig 26.8) }\end{array}$ & Coarse subrounded & 1 & / & $12 \mathrm{~cm}$ \\
\hline Grignon & / & 1 & 1 & 1 & 1 & 1 \\
\hline Hambacher Forst & / & 1 & 1 & 1 & 1 & / \\
\hline \multicolumn{7}{|c|}{ CULTIVATOR } \\
\hline Butser & / & / & / & / & 1 & 1 \\
\hline Deherain & $\begin{array}{l}\text { Little } \\
\text { compac- } \\
\text { tion }\end{array}$ & Very loose & $\begin{array}{l}\text { Numerous peds, bird } \\
\text { foot-shaped cracks (fig } \\
\text { 26.9) }\end{array}$ & Little organic matter & & $10-12 \mathrm{~cm}$ \\
\hline Grignon & I & 1 & 1 & 1 & / & 1 \\
\hline Hambacher Forst & $\begin{array}{l}\text { Little } \\
\text { compac- } \\
\text { tion }\end{array}$ & Crack porosity & $\begin{array}{l}\text { Peds broken with clean } \\
\text { and straight edges (fig } \\
26.10 \text { ) }\end{array}$ & Plant remains buried deeply & 1 & $12 \mathrm{~cm}$ \\
\hline
\end{tabular}

Table 4 Abundance of biological activity in relation to the type of manuring carried out on the Deherain plots

\begin{tabular}{|c|c|c|}
\hline & MICROFAUNA & MESOFAUNA \\
\hline \multicolumn{3}{|c|}{ UNCULTIVATED } \\
\hline Surface & ++++ & ++++ \\
\hline At depth & ++++ & ++ \\
\hline \multicolumn{3}{|c|}{ SPADE WITHOUT MANURING } \\
\hline Surface & 0 & ++ \\
\hline At depth & +++ & + \\
\hline \multicolumn{3}{|c|}{ SPADE PURE STRAW } \\
\hline Surface & + & + \\
\hline At depth & +++ & +++ \\
\hline \multicolumn{3}{|c|}{ SPADE HUMIDIFIED STRAW } \\
\hline Surface & + & + \\
\hline At depth & ++ & ++ \\
\hline \multicolumn{3}{|c|}{ CULTIVATOR WITHOUT MANURING } \\
\hline Surface & + & 0 \\
\hline At depth & ++ & 0 \\
\hline \multicolumn{3}{|c|}{ CULTIVATOR STABLE LITTER } \\
\hline Surface & + & 0 \\
\hline At depth & ++ & +++ \\
\hline
\end{tabular}

$\mathrm{O}$ = absent; + = trace; ++ : not very abundant; +++ = abundant; ++++ : very well-developed 


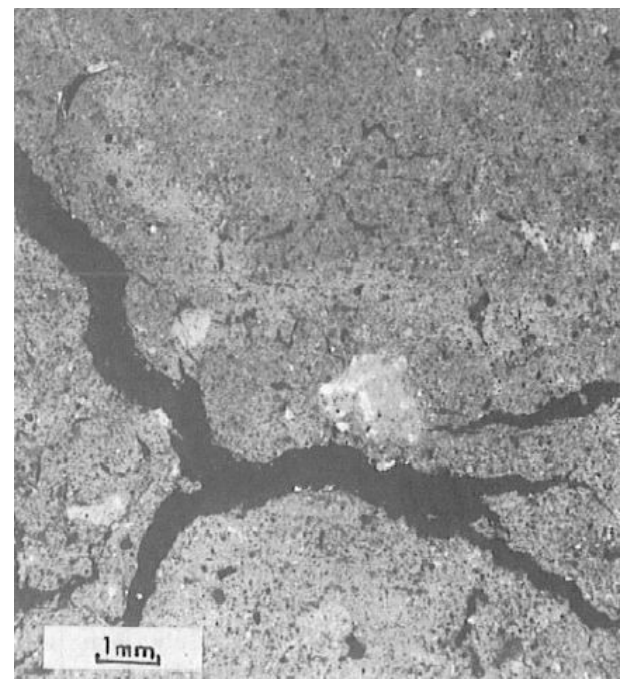

Fig. 1 : Butser. uncultivated plot under grassland : a bird feet-shaped fissure.

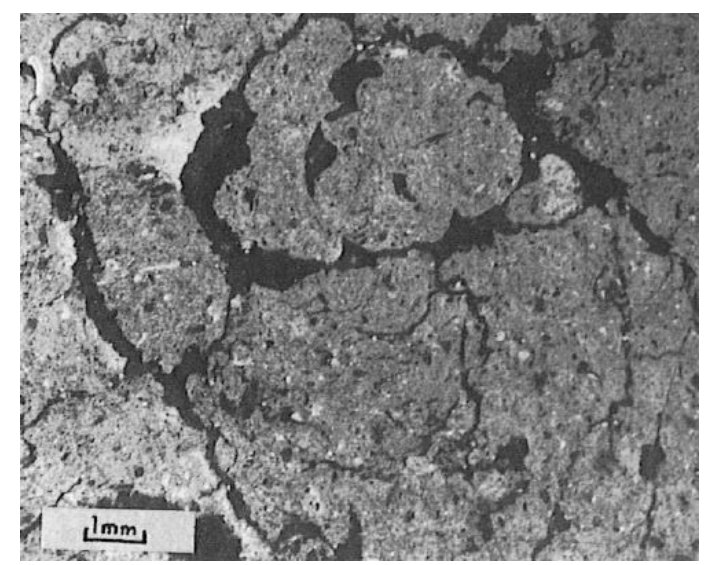

Fig. 2 : Deherain, uncultivated plot under grassland : compacted pcds with an animal burrow.

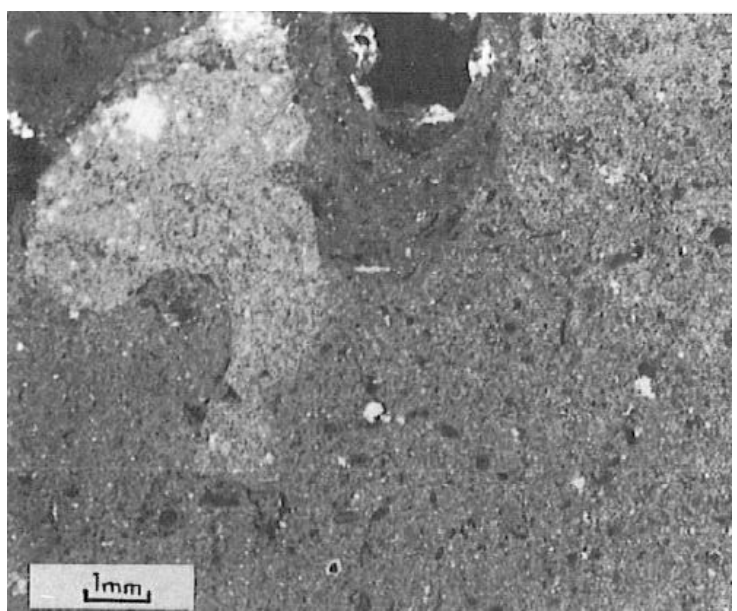

Fig. 3 : Grignon : uncultivated plot under forest : compact soil with little bird feet-shaped fissures and an animal burrow. 


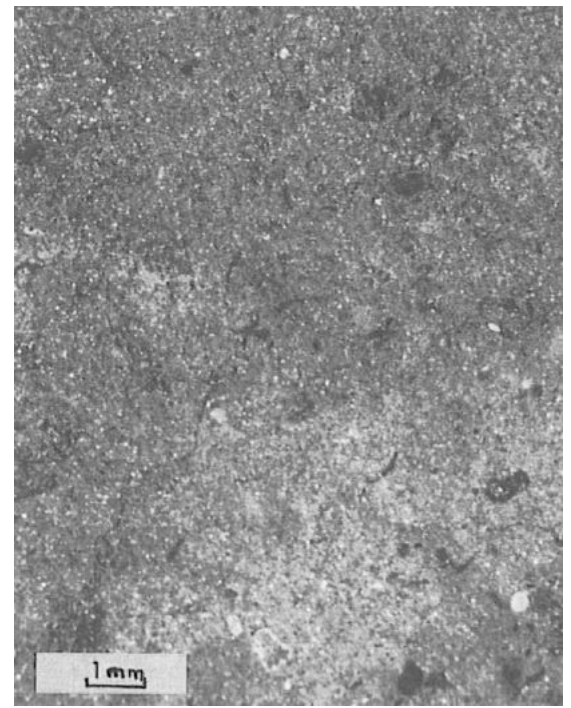

Fig. 4 : Hambacher Forst. uncultivated plot under Forest : compact soil.

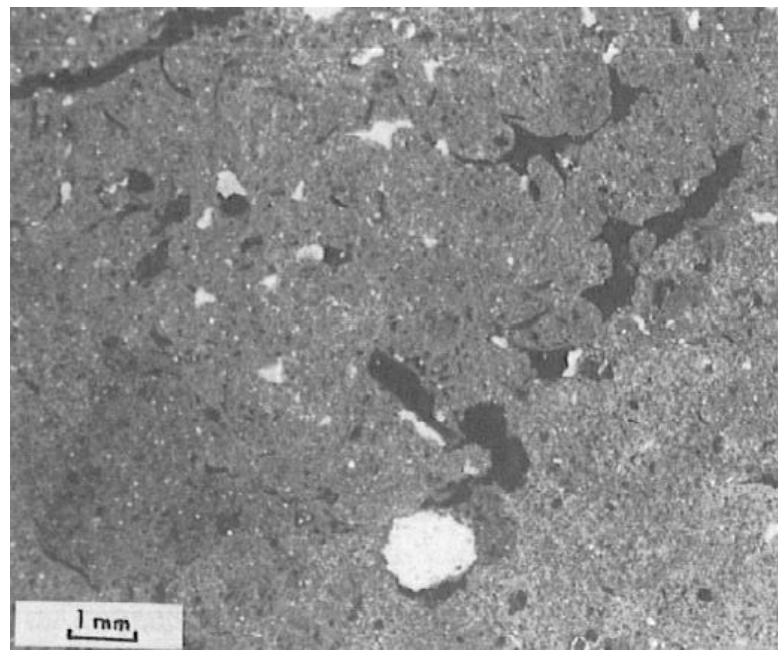

Fig. 5 : Grignon, plot worked with 21 hoe : quite compact packing of soil with 21 porosity of starshaped concave walls.

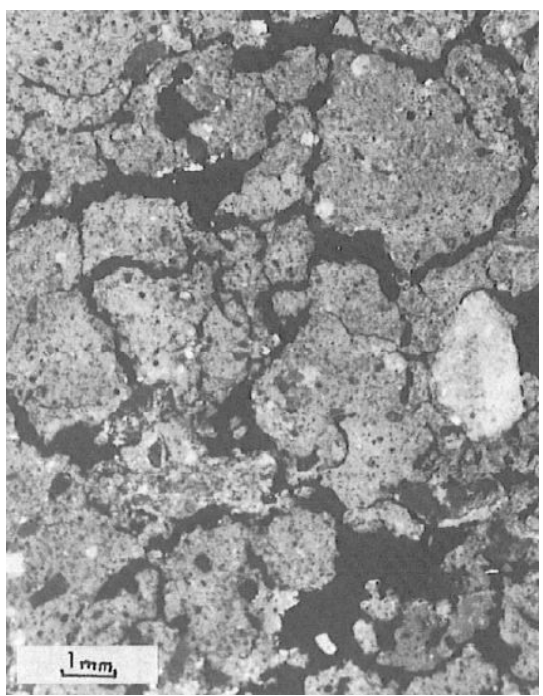

Fig. 6 : Butser, soil ploughed with an ard : medium compacted soil with quite angular pads. 


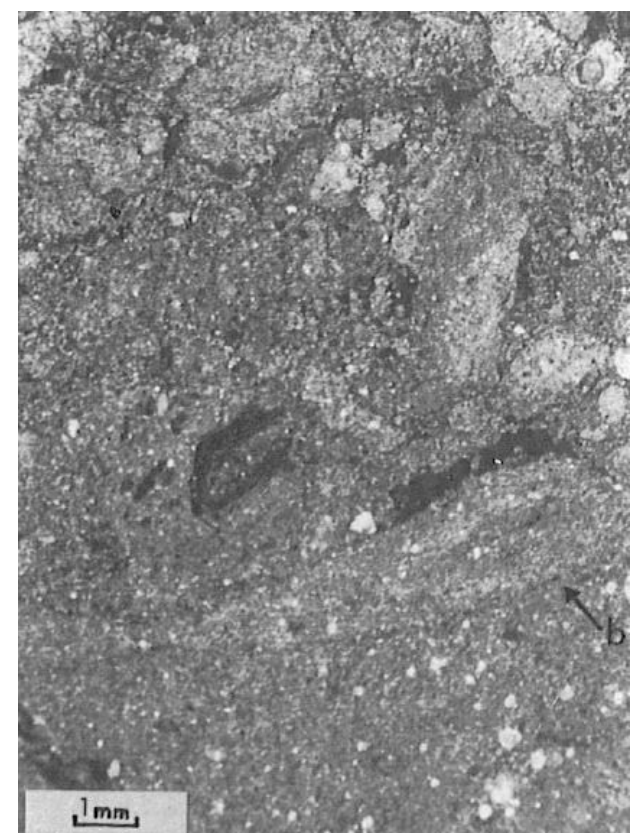

Fig 7 Hambacher Forst plot worked with an ard : compact soil with round peds floating in the groundmass and a plough pan limiting the Ap horizon.

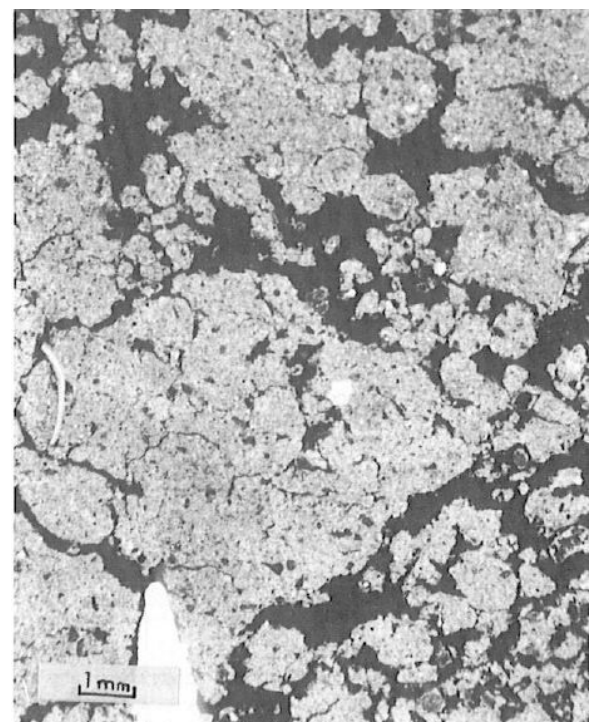

Fig. 8 : Déhérain, plot worked with a spade : little compaction with coarse sub-rounded peds.

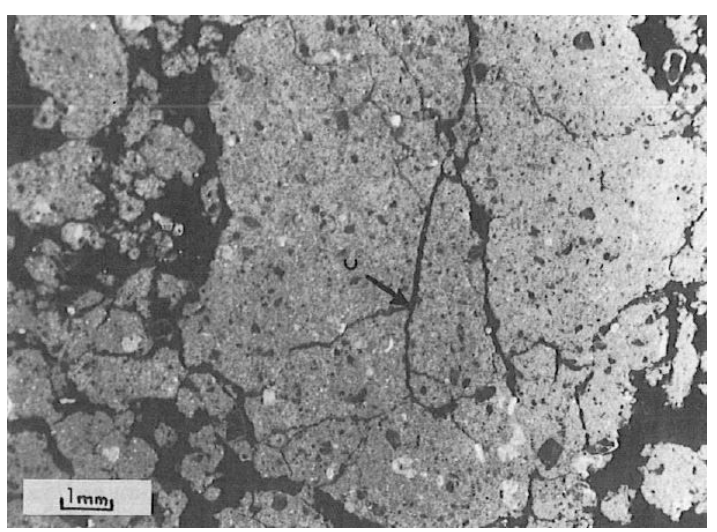

Fig 9 : Déhérain plot worked with a cultivator : little compacton with numerous big peds including the original bird feet-shaped cracks 


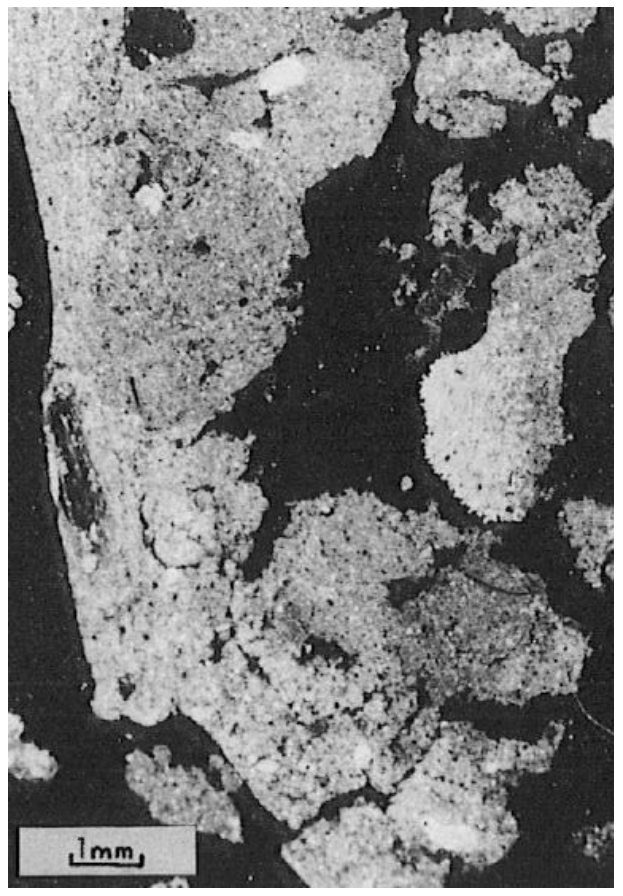

Fig. 10 : Hambacher Forst. plot worked with a cultivator : little compaction of peds. broken with clean and straight edges. 